\title{
The Role of Zakat in Human Development
}

\author{
Khairul Azhar Meerangani ${ }^{1}$ \\ Fakulti Keilmuan Islam, Kolej Universiti Islam Melaka, Malaysia \\ doi) $10.15408 /$ sjsbs.v6i2.11037
}

\begin{abstract}
:
Zakat is one of the major economic sources for Islamic countries. The efficiently and systematically of zakat management able to propel it's potential as an instrument of human development especially among Muslims. The optimum utilization of zakat funds is essential to improving the quality and potential of every Muslim. In Malaysia, zakat is administrated by the Islamic Religious Council (IRC) in every state. The IRC is responsible for determining the beneficiary's qualification and the type of relief that is appropriate based on the background of each recipient so that the relief can be utilized to fulfill their needs. This study aims to assess the potential of zakat in developing the quality of Muslims in Malaysia by highlighting the practice of each IRC in distributing relief to each qualified zakat recipient. The distribution statistics and the form of programs provided by the IRC were analyzed descriptively to see the potential of zakat itself practically in improving the quality of Muslims. The study found that the IRC has provided various programs aimed at improving the quality of asnaf through equitable distribution of economics, social welfare distribution, human capital production and upgrading of education. Thus, every Muslim, especially zakat payers, should take the opportunity to equally engage with the IRC to ensure that zakat funds can be optimized for the development of Muslims in Malaysia.
\end{abstract}

Keywords: Zakat, Human Development, Collection, Distribution, IRC

\begin{abstract}
Abstrak:
Zakat adalah salah satu sumber ekonomi utama bagi negara-negara Islam. Pengelolaan zakat yang efisien dan sistematis dapat mendorong potensi itu sebagai instrumen pengembangan manusia terutama di kalangan umat Islam. Pemanfaatan dana zakat yang optimal sangat penting untuk meningkatkan kualitas dan potensi setiap Muslim. Di Malaysia, zakat dikelola oleh Dewan Agama Islam (IRC) di setiap negara bagian. IRC bertanggung jawab untuk menentukan kualifikasi penerima dan jenis bantuan yang sesuai berdasarkan latar belakang masing-masing penerima sehingga bantuan tersebut dapat digunakan untuk memenuhi kebutuhan mereka. Penelitian ini bertujuan untuk menilai potensi zakat dalam mengembangkan kualitas umat Islam di Malaysia dengan menyoroti praktik setiap IRC dalam mendistribusikan bantuan kepada setiap penerima zakat yang berkualitas. Statistik
\end{abstract}

\footnotetext{
* Diterima: 24 Desember 2018, Revisi: 22 Februari 2019, Dipublikasi 1 April 2019.

${ }^{1}$ Senior Lecturer (PhD), Fakulti Keilmuan Islam, Kolej Universiti Islam Melaka, Malaysia. E-mail: khairulazhar@kuim.edu.my
} 
distribusi dan bentuk program yang disediakan oleh IRC dianalisis secara deskriptif untuk melihat potensi zakat itu sendiri secara praktis dalam meningkatkan kualitas umat Islam. Studi ini menemukan bahwa IRC telah menyediakan berbagai program yang bertujuan untuk meningkatkan kualitas asnaf melalui distribusi ekonomi yang merata, distribusi kesejahteraan sosial, produksi sumber daya manusia dan peningkatan pendidikan. Dengan demikian, setiap Muslim, terutama pembayar zakat, harus mengambil kesempatan untuk secara setara terlibat dengan IRC untuk memastikan bahwa dana zakat dapat dioptimalkan untuk pengembangan umat Islam di Malaysia.

Kata kunci: Zakat, Pengembangan Manusia, Pengumpulan, Distribusi, IRC

\section{Introduction}

The construction of a high-quality human requires strong financial resources to ensure that every planned goal can be achieved. Zakat is one of the instruments that plays an important role in strengthening the Muslims and ensuring justice and social stability through the reduction of income gap among the community (Patmawati, 2008). Through Islamic obligations, Islam has established a caring and responsible nature in every Muslim so they take care about the needy in society (al-Qardawi, 1991). This is as stated by Allah SWT:

Translation: The believing men and believing women are allies of one another. They enjoin what is right and forbid what is wrong and establish prayer and give zakat and obey Allah and His Messenger. Those - Allah will have mercy upon them. Indeed, Allah is Exalted in Might and Wise. (Surah al-Tawbah 9: 71)

Zakat has been impeded in the second year of hijrah, whereas the giving and donation was voluntary only (Ali Sarbiji, 1993). Islam has raised the status of the recipients of zakat in which the burden of responsibility to assist them has been handed over to the capable Muslims. Mustafa al-Siba'i (2012) states that granting the right to the person as stated in the verse is in the condition that they raise the head to receive it with dignity. This is because the gift is a right that has been assigned to them as a worker who receives a salary for his work. This has illustrated the zakat privilege itself as a pillar of the structure of the Islamic economic system in developing socio-economic society comprehensively. Therefore, every individual who is capable of supposedly should embrace this third pillar of Islam with involvement in the production and distribution of zakat (Ghazali, 2005). If this claim is neglected, then the preservation and excellence of zakat instruments in realizing the welfare of the ummah will not be fully realized. Through the zakat system, the socioeconomic gap between the rich and the poor can be bridged through the consciousness of those who have the ability that the needy people also have the right and certain parts of their property (Mahmood, 2003). 
Muslims nowadays face various challenges in the political, economic and social aspects that require a sustained community support system in the realization of human well-being. Thus, zakat is seen as one of the mechanisms of effective civil society catalysts and in accordance with the current world circulation and development. The administration of zakat funds in Malaysia is managed by the Islamic Religious Council (IRC) as provided in the respective State Administration Enactments (Hafiz and Nabilah, 2016). This specific scope and jurisdiction can open space to IRC to focus on managing zakat collection and distribution efficiently. As a result, based on annually statistical reports, there is an increasing trend in the collection and distribution of zakat funds in Malaysia. As an example, for 2015, almost RM3 billions of zakat funds have been collected and then distributed to qualified recipients. This increase based on high level of awareness among Muslim societies to issue zakat as well as the efficiency of the IRC itself in controlling the fund (Muhammad et.al, 2005). Details on the collection and distribution statistics of each state can be seen in the following table:

\begin{tabular}{|l|c|c|c|c|}
\hline \multirow{2}{*}{ STATE } & \multicolumn{2}{|c|}{ COLLECTION } & \multicolumn{2}{c|}{ DISTRIBUTION } \\
\cline { 2 - 5 } & $\mathbf{2 0 1 5}$ & $\mathbf{2 0 1 6}$ & $\mathbf{2 0 1 5}$ & $\mathbf{2 0 1 6}$ \\
\hline Johor & $239,931,006.61$ & $250,436,479.20$ & $244,238,743.65$ & $296,999,713.65$ \\
\hline Kedah & $133,954,548.76$ & $140,448,128.00$ & $144,955,284.85$ & $162,732,368.00$ \\
\hline Kelantan & $161,908,949.42$ & $162,678,760.00$ & $196,744,773.04$ & $173,148,849.00$ \\
\hline Melaka & $65,968,448.90$ & $70,537,675.73$ & $71,964,251.44$ & $75,367,964.80$ \\
\hline Negeri Sembilan & $95,247,317.97$ & $104,760,388.36$ & $96,935,984.93$ & $102,867,136.92$ \\
\hline Pahang & $118,082,517.70$ & $122,248,982.33$ & $113,421,941.00$ & $134,066,490.00$ \\
\hline Pulau Pinang & $92,844,818.96$ & $96,781,464.11$ & $101,329,498.13$ & $100,962,507.09$ \\
\hline Perak & & & & $143,832,214.00$ \\
\hline Perlis & $132,584,966.22$ & $151,181,069.12$ & $164,264,513.67$ & $182,500,000.00$ \\
\hline Selangor & $158,633,000.00$ & $215,315,000.04$ & $123,570,316.00$ & $697,494,013.00$ \\
\hline Terengganu & $627,225,101.00$ & $673,736,282.00$ & $676,251,478.00$ & $165,894,689.77$ \\
\hline Sabah & $126,639,148.45$ & $133,360,064.38$ & $122,041,037.35$ & $64,957,773.60$ \\
\hline Sarawak & $61,795,695.17$ & $63,704,056.64$ & $72,904,222.68$ & $48,363,149.00$ \\
\hline Wilayah & $68,573,996.00$ & $72,082,740.00$ & $44,984,662.00$ & $444,719,832.00$ \\
\hline Persekutuan & $565,830,672.18$ & $589,296,523.84$ & $608,724,857.00$ & \\
\hline & & & $2,782,331,563.74$ & \\
\hline
\end{tabular}

Table 1: Statistics on Collection and Distribution of Zakah in Malaysia (Source: JAWHAR) 
Based on the above statistics, the amount of zakat collection has increased by $7.5 \%$ from 2015 to 2016, thus allowing the distribution of zakat to be increased by $0.4 \%$ for 2016 compared to the previous year. This increase proves that zakat is a major source of Muslims who, if well-utilized, is able to provide a shift in the quality of the lives of Muslims in Malaysia.

\section{Methodology}

The study was conducted qualitatively aiming to review the list of zakat distribution program which focuses on human development in Malaysia. This information is obtained through documents contained in the zakat center website regarding zakat distribution statistics and interviews with authorized parties at the Islamic Religious Council to obtain more detailed and holistic data on the policies adopted by them in distributing zakat funds. The distribution statistics and the form of programs provided by the IRC were analyzed descriptively to see the potential of zakat itself practically in improving the quality of Muslims. The program are analyzed in a comparative and inductive way to identify the role of zakat in support of human development program in Malaysia. In tracking the development of zakat distribution program in Malaysia, the historical design method is used to evaluate the form of practice applied by the Islamic Religious Council in each state in managing the distribution of these funds. Case study design is also used in this study. Case study is a form of ethnographic study that focuses on certain elements that underlie a particular case in order to understand the justification behind the occurrence of such a matter (Frankeal and Wallen, 2006). The position of each zakat funds recipient will be refined by taking into account the current development of human in Malaysia to verify enable the zakat funds distribution process to be more effective.

\section{Zakat and Human Development}

The IRC itself has implemented various reforms and improvements in aspects of service to the community in line with current developments today (Mujaini, 2005). One of the main emphasis is on the distribution of zakat funds to qualified recipients (al-mustahik). Various programs have been designed and implemented in order to ensure that the collected zakat funds are successfully distributed to improve the quality and standard of living of each beneficiary thus helping them to escape the difficulties and difficulties encountered. So in this study, the program and the form of zakat distribution implemented by each state will be seen to assess its potential in developing Muslims in Malaysia in terms of economic, education and social aspects. 


\section{a) Economy Development}

Zakat funds can be utilized for economic development programs aimed at raising economic standards of the asnaf through the provision of business opportunities and entrepreneurship (Patmawati, 2008). By assisting these groups directly involved in these areas, zakat has played a role as a balanced distribution of economic instruments to reduce poverty, improve the quality and quality of life, provide a comfortable and prosperous life thus leading to the creation of a prestigious nation in the future (Zarina et.al, 2012). Equal redistribution of wealth in society can actually bridge the gap between wealthy and poor. In this case, zakat plays a role in controlling the growth of each individual's income in order to be subject to the principle of self-sufficiency of all human beings. This can prevent the convergence of property among certain groups of people in the society as expressed through the following word of God:

Translation: And what Allah restored to His Messenger from the people of the towns - it is for Allah and for the Messenger and for [his] near relatives and orphans and the [stranded] traveler - so that it will not be a perpetual distribution among the rich from among you. (Surah al-Hasyr 59: 7)

This prevention actually has significant significance in restoring Islamic economics in a stronger and more advanced stage and preventing property from being restricted in the grip of the rich (Mahmood, 2001). Typically, the poor only have limited purchasing capabilities due to low income constraints. Therefore, they will usually face difficulty in accommodating and completing their living needs (Noorbiah et.al, 2017). This reduction in purchasing power led to these groups having to make a choice by ensuring that only goods were actually under their financial capabilities. Indirectly, this situation has led to an increase in the tendency to use among the rich. However, the rich are more likely to use luxury goods and less focus on basic necessities. This has led to a lack of demand in basic necessities leading to a reduction in the supply of such products by producers and entrepreneurs (Noorbiah et.al, 2017). Thus, when this is the zakat play an important role in stabilizing the imbalance of the current economic cycle.

The transfer of property from the zakat payers to the asnaf is able to increase their purchasing power on daily basic necessities thus leading to increased demand for goods in the market where beneficiaries will spend most of their funds for their daily use. The increase in buying power among these asnaf can stimulate the growth and development of the country's economy through increased demand and supply activity in the market (Patmawati, 2008). It can therefore be seen that zakat collection and distribution activities will not only play a role in creating a balanced distribution of the economy, but also in order to generate national income to a higher level. Based on the Economic Report for 2017/2018, during the first 6 months of 2017 the Malaysian economy posted a 
healthy growth of 5.7 percent. This growth is stimulated by strong domestic demand and is supported by a stable and robust external sector (Zarina et.al, 2012).

At the same time, the increase in consumption from the asnaf to meet the demands of life will increase the demand for basic goods and products and generate employment and business opportunities to the community. This increase in opportunities is able to provide new platforms to be explored by various parties and indirectly reduce unemployment in the country (Hairunnizam et.al, 2004). Unemployment has led to a decline in productivity in the country where the number of productive employments is at a minimal level leading to an increase in poverty rates that risk the social crisis in society. Apart from being a market-driven consumer, potential asnaf have also been polished as operators and producers to actively engage in the current market. IRC provides various aid packages in the field of entrepreneurship such as injection of financial capital and tools to start a business. In addition, program participants are also guided through business skills courses as well as ongoing monitoring to ensure they have a high level of competitiveness and thus have the most precise motivation to get out of the poverty zone they have been shackling for so long. Here are some of the entrepreneurship programs provided by IRC:

\begin{tabular}{|l|l|}
\hline \multicolumn{1}{|c|}{ TYPE OF RELIEF } & \multicolumn{1}{c|}{ EXAMPLE OF PROGRAMME } \\
\hline 1) Course and Skill Training & Pulau Pinang \\
2) Business Capital & - Gerak Asnaf Katering \\
4) Business Opportunity & - Gerak Asnaf Jahitan \\
5) Business Recuperation & - Gerak Asnaf Tani \\
& - Gerak Asnaf Niaga \\
& - Atrium dan Café \\
& Kedah \\
& - Sewing Skill Centre \\
& Selangor \\
& - Asnaf Zakat Entrepreneurs Group (KUAZ) \\
& - Hijrah Kerjaya Asnaf \\
& - Forum of Economy \\
& - Entrepreneurship Courses \\
& Wilayah Persekutuan \\
& - Taxi Purchase Deposit \\
& - Agricultural Relief \\
& - MAIWP Grocery Stores \\
\hline
\end{tabular}

Table 2: Economic Relief (IRC) 
As a result of the stepping stone provided by this zakat institution, the asnaf will strive to advance their economy, thereby increasing their income beyond the qualifying limits of zakat recipients. This situation can indirectly alter zakat recipients into zakat payers and automatically withdraw from the zakat list of zakat. The initiative implemented by the MAIN through entrepreneurial programs provided could potentially produce many entrepreneurs and create business opportunities for the recipients of zakat. The productive zakat can generate a balanced economic growth and distribution and contribute to the well-being of the community.

\section{b) Social Development}

The distribution of zakat aims to develop the social quality of society by meeting the needs of asnaf groups such as shelter, subsistence and health care. The existence of the disadvantaged in a country is a commonplace that is difficult to avoid. The imbalance that exists in the socio-economic aspects of the rich and the poor can potentially undermine the society as a whole in addition to affecting the harmony of social life if left unchanged (Abd Rahman, 2013). Therefore, social justice-oriented approaches such as zakat should be presented as a form of settlement to this problem. Social welfare preservation is an important agenda that needs to be addressed to realize the goal of improving social quality in society. The provision of quality policies, programs and services should be created to meet the basic needs of the community and address social issues that threaten the lives of the people (Abd Rahman, 2007). Various social support and social support programs need to be implemented as a social protection network system in ensuring that marginalized people are not burdened with social problems such as poverty, work disabilities as a result of disabilities and other social barriers to help them compete actively in the field of life (Che Bakar et.al, 2007). Based on this approach, Islam has obliterated the distribution of zakat as a mechanism for the transfer of wealth from the rich to be given to those who are entitled and need help such as the poor, the poor and so on. Here are some of the charity programs that have been implemented by IRC namely:

\begin{tabular}{|l|l|}
\hline TYPE OF RELIEF & EXAMPLE OF PROGRAM \\
\hline 1) Build / Repair Home & Pulau Pinang \\
2) Disaster / Emergency & - Hemodialysis Centre \\
3) Medical Treatment & - Mobile Clinic \\
4) Monthly Financial and Foods Relief & - Muallaf Transit House \\
5) Mortuary Management & Kedah \\
6) Deposits / Home Rental / Taxes and Bills & - Free Market \\
7) Musafir/Muallaf Relief & Selangor \\
\hline
\end{tabular}




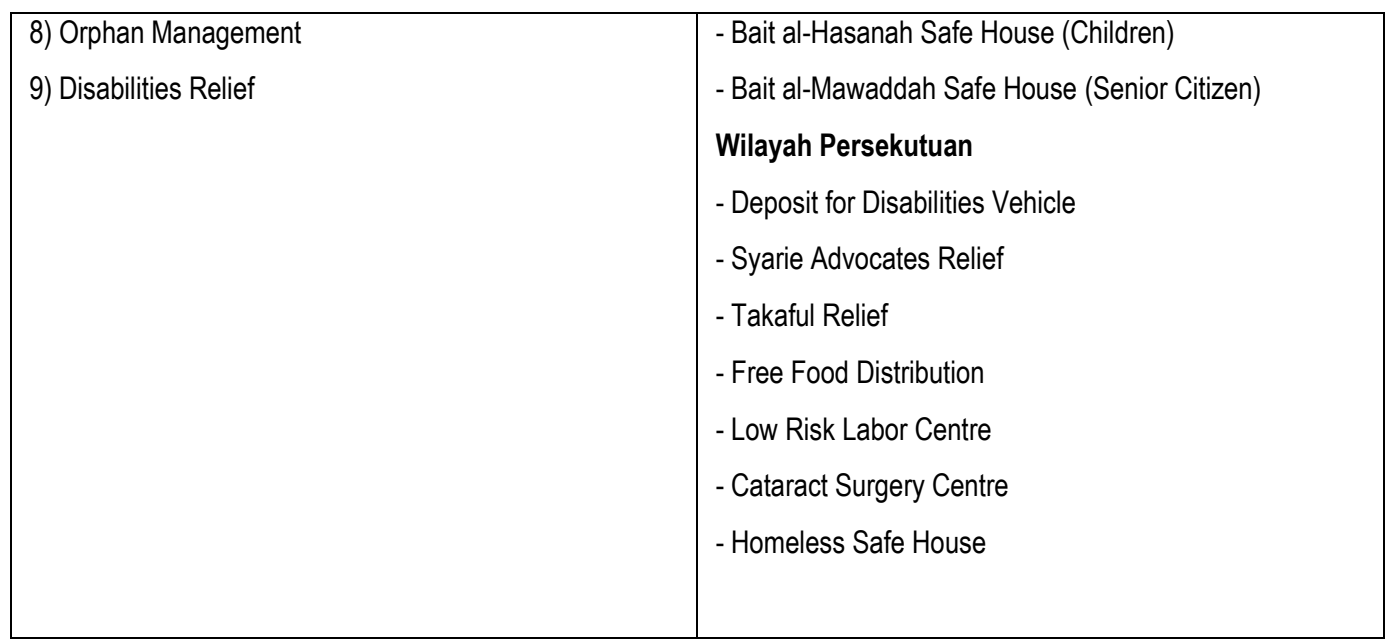

Table 3: Social Relief (IRC)

Looking at the list of programs implemented, we can assess the level of seriousness of IRC in helping the community. Various programs are implemented to help the asnaf enjoy better and prosperous lives for themselves and their families. Assistance includes protection, financial provisions, basic needs and welfare benefits. In addition to being a socio-economic balancer of the community, zakat is also able to nourish the relationship of friendship and preserve the harmony of social life as expressed through the following verse:

Terjemahan: Take, [O, Muhammad], from their wealth a charity by which you purify them and cause them increase, and invoke [Allah 's blessings] upon them. Indeed, your invocations are reassurance for them. And Allah is Hearing and Knowing. (Surah al-Tawbah 9: 103)

In order to create a prosperous and harmonious community, zakat also strives to liberate people from the chaos of poverty through provision of livelihood to those who need either temporarily or permanently. These groups will be given due diligence to ensure that they can live a life of certainty. In addition, zakat also aims to help those who face unexpected financial and material problems such as debts, illnesses and certain disasters although they are in a category that does not require assistance (Hairunnizam et.al, 2004). The zakat focus on eradicating poverty can be seen through the allocation given to asnaf in the poor and poor category by 2015 of RM1.2017 million or $43.94 \%$ of the total zakat distribution issued by the Islamic Religious Council in each state. This suggests the level of seriousness of the IRC in defending and removing any asnaf involved in poverty alleviating their lives.

Islam gives serious attention to the agenda of poverty eradication as it is one of the contributing factors to the occurrence of crime in society. In addition, poverty can also trigger hate groups and hostility between the rich and poor thus leading to social conflict in society. Accordingly, Muslim scholars have determined that the aspect that should be emphasized and the main focus on 
zakat distribution is the poverty eradication agenda (Sabri and Riki, 2016). However, the socioeconomic development of the poor and poor asnaf is a serious issue that requires careful planning and cannot be dealt with only seasonally. Therefore, short-term and long-term project planning in developing these groups should be implemented in parallel. Zakat can be allocated in the form of continuous assistance such as subsistence poor livelihoods, natural disaster contributions, protection from misfortune and difficulties and medical assistance as the need is urgent and immediate. In addition, zakat can also be used to finance long-term development projects such as education financing and the provision of entrepreneurship capital that will benefit more in the future for this group. Their souls need to be motivated to be independent by way of capitalizing on zakat distribution as a source of capital in advancing their own economies so that they can eventually remove themselves from the chains of poverty (Joni, 2005).

\section{c) Education Development}

Apart from focusing on economic and social development, IRC also gives attention to education development agenda in society. Through this provision, the asnaf can improve their quality and identity and produce skilled and competitive asnaf (Che Bakar et.al, 2007). The upgrading programs of education provided by the IRC have opened up opportunities for asnaf children to study at a higher level and reduce illiteracy rates in society which ultimately promises a brighter future for them and their families. Through these programs as well, the IRC can open the minds of the asnaf to venturize themselves to the outside world. This is because of the difficulty of living that has led some of them to be afraid to deal with the outside world because of lack of self-confidence to associate with the community (Azman and Martiah, 2014). These asnaf people actually have a high interest in learning but due to financially constraints in paying tuition and study fees, most of them continue to take a short break by ending learning sessions despite the great potential to achieve excellence in the lessons (Faeez and Kamarul, 2011).

Problems with dropouts in the lessons that occur when someone is unable to continue their studies is one of the cancers that kills potential talents in the country. This disruption certainly brings huge losses to the country and exposes the country with a serious loss of quality-generation generation if not dealt with immediately. Therefore, the agenda to address the problem of dropout in this lesson has been taken seriously, especially since the 1960s and the government has taken the necessary steps based on the recommendations obtained through the presentation of the Murad Report 1972. A comprehensive study conducted on urban areas, big cities as well as rural and urban areas find that $40 \%$ of schoolchildren in Malaysia have dropped out of school (Kamal, 1988). This report 
concludes that the main factor in the drop in this lesson is due to the socioeconomic status of families where children from low-income families are often left out in the lesson due to parents' inability to bear the burden of their children's schooling. The low level of parent education is also seen as influencing their awareness of the importance of education among children. Based on the report, several initiatives have been introduced by the government in providing equal opportunity for all members of the community to obtain quality education such as exemption from school fees, scholarship granting and provision of aid incentives covering health services, quality food and textbook lending provided for free (Kamal, 1988)

The government has given huge allocations in education from year to year for 2015 to 2017, almost RM42 billion has been spent annually in ensuring every citizen gets a quality and quality education service. This proves that the education sector has become the main agenda of the government in transforming the nation's development. However, the provisions of the government are only publicly available to all citizens and less particularly paying attention to the asnaf groups so that they can get out of poverty and change lives better. Hence, here is where IRC plays an important role in identifying the asnaf who are left out in the lesson to devise appropriate programs to help improve the quality of their self and the level of their education. Various assistance has actually been provided by zakat institution in generating educational excellence among asnaf:

\begin{tabular}{|l|l|}
\hline TYPE OF RELIEF & EXAMPLE OF PROGRAMME \\
\hline 1) Education Scholarship & Pulau Pinang \\
2) Seminar and Workshop (Student) & - Prep Night Class \\
3) Tuition & - Smart Caliph Camp \\
4) Incentives of Excellence & - Mutiara PDCA \\
& Sarawak \\
& - Ibn Khaldun Education Fund \\
& Selangor \\
& - University College of Islam Selangor Allocation \\
& - School Education Program \\
& - KAFA Teacher Allowance \\
& Wilayah Persekutuan \\
& - Sekolah Menengah Integrasi Sains Tahfiz (SMISTA) Allocation \\
& - PUSRAWI International College of Medical Science (PICOMS) \\
Allocation \\
- Baitulmal Professional Institute Allocation \\
- Huffaz al-Quran Encouragement Relief
\end{tabular}




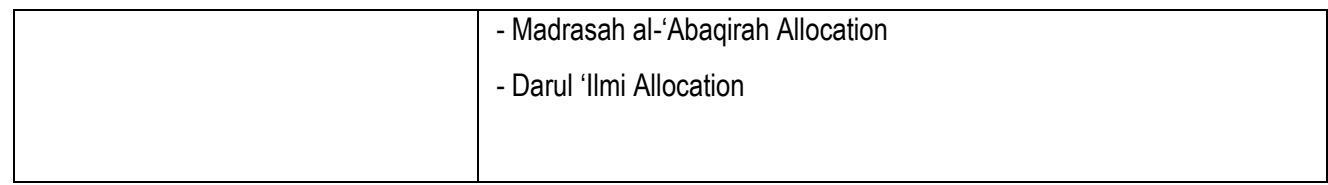

Table 4: Education Relief (IRC)

The programs implemented proved that the IRC is serious in raising the level of education of the asnaf as part of a long-term plan to help them enjoy a better life in the future. Education is an important ticket in transforming the life of the asnaf especially among the poor and poor and elevates their position to a higher level as stated in the following verse:

Translation: Allah will raise those who have believed among you and those who were given knowledge, by degrees. And Allah is Acquainted with what you do. (Surah alMujadalah 58: 11)

Continuous learning at every level begins at a low level of schooling so high-level studies can provide asnaf groups with a variety of quality packages, thus providing a good job opportunity to ensure a bright future. A good career as a result of continuous education is able to remove the asnaf from the pungent poverty that shuts them. A good level of graduation in higher education can ensure good care and at the same time can address unemployment problems among young people in Malaysia. Education zakat aid provided by IRC is seen to inject awareness and spark the spirit of success amongst the asnaf after seeing the success of other program participants out of poverty shackles thereby enhancing their standard of living. Mentalities and negative perceptions inherent in the asnaf should be altered so that they being able to transform into productive societies. These groups are also able to model and source inspiration to other asnaf in raising awareness for a better life. Therefore, each asnaf needs to leverage all the assistance and opportunities afforded to prove to the community that they are also eligible and entitled to change and succeed.

\section{Conclusion}

The dedication of zakat in Islam aims to nurture justice and balance in human life as well as to defend those who are tested with poverty and distress. Through the perfect and systematic distribution of zakat, the economy of the Muslims can be raised to a higher level through business and entrepreneurial programs. This will result in linking effects where strong and balanced economic growth will create a strong social welfare system in turn improving the level of education and the quality of human capital in the country. Hence, this effort requires careful planning through the mobilization of the workforce and strategies organized through a strong and powerful organizational body (Shofian and Amir, 2002). In other words, this agenda is difficult to realize if the distribution of zakat is carried out individually and alone as the goal of liberating 
humanity from poverty and producing quality human capital is not an easy task. The country's economic growth has significant impact on the increase of zakat. Thus, the zakat position as one of the main social institutions for Muslims needs to be expanded and enhanced through a sustainable and intact management of the institution to build a new dimension especially in the distribution of zakat so that the zakat institution becomes a competitive institution and can play its role effectively local, regional and universal levels (Hairunnizam et.al, 2004). The efforts to uphold the excellence of Muslims have become the main agenda for every Muslim nation and zakat institutions can be a potentially important mechanism in promoting the development agenda of Muslims especially in Malaysia.

\section{References}

Aji, Ahmad Mukri; Yunus, Nur Rohim. Basic Theory of Law and Justice, Jakarta: Jurisprudence Institute, 2018.

Khairul Azhar Meerangani (2017) Model Agihan Dana Zakat al-Riqab Berteraskan Maqasid al-Syariah: Satu Kajian Awal dalam Isu-Isu Kontemporari dalam Zakat, Wakaf dan Filantropi Islam, eds. Najahudin Lateh et.al, Shah Alam: ACIS UTM

Maggalatung, A Salman. "Hubungan Antara Fakta Norma, Moral, Dan Doktrin Hukum Dalam Pertimbangan Putusan Hakim," dalam Jurnal Cita Hukum, Vol. 2, No. 2 (2014).

Mahmood Zuhdi Ab Majid (2001) "Falsafah Agihan: Keberkesanan dan Ketelusan dalam Pengagihan Zakat", (Makalah, Konvensyen Zakat Kebangsaan, Renaissance Palm Garden Hotel, Putrajaya)

Mohamad Sabri Haron dan Riki Rahman (2016) “Pengagihan Zakat Dalam Konteks Kesejahteraan Masyarakat Islam: Satu Tinjauan Berasaskan Maqasid Al-Syari'ah", Labuan e-Journal of Muamalat and Society 10:. 129-140

Muhammad Hafiz Badarulzaman dan Siti Nabilah Sulaiman (2016) "Undangundang Pentadbiran dan Pengurusan Zakat di Malaysia: Perbandingan antara Enakmen Negeri-Negeri" (Prosiding, The $5^{\text {th }}$ International Conference of Law and Society (ICLAS V), UNISZA Kuala Terengganu).

Muhammad Muda, Ainulashikin Marzuki and Amir Shaharuddin (2005) "Internal and External Factors Influencing Individual's Participation in Zakat: Preliminary Results", Journal of Muamalat and Islamic Finance Research 2(1): 77-92.

Muhammad Ra'fat 'Uthman (2010) al-Zakah fi al-Amwal wa Ma Yattasil biha min Qadaya Maliyyah Mu'asirah, Qahirah: Maktabah Wahbah 
Muhammad Zulfiqar (2014) Zakah According to the Quran and Sunah, Riyad: Darussalam Publishers

Patmawati Ibrahim (2008) "Pembangunan Ekonomi Melalui Agihan Zakat: Tinjauan Empirikal", Jurnal Syariah, 16(2): 223-244

Rahman, Azman Ab; Anwar, Siti Martiah. Dana Zakat dalam Pendidikan Asnaf dan Sumbangannya Terhadap Ekonomi Malaysia, (Prosiding, PERKEM ke-9), (2014).

Sanep Ahmad dan Hairunnizam Wahid (2005) "Persepsi Agihan Zakat dan Kesannya Terhadap Pembayaran Zakat kepada Institusi Formal", Jurnal Ekonomi Malaysia 39: 53-69

Siti Noorbiah Mat Rejab et.al (2017) Zakat Sebagai Mekanisme Agihan Ekonomi Seimbang: Aplikasi Lembaga Zakat Selangor dalam Isu-Isu Kontemporari dalam Zakat, Wakaf dan Filantropi Islam, eds. Najahudin Lateh et.al, Shah Alam: ACIS UiTM

Talib Abdul Rahman. "Konsep Tagihan Zakat kepada Asnaf menurut Perspektif Islam", Jurnal Pengurusan JAWHAR 7 (2): (2013).

Wahid, Hairunnizam; Ahmad, Sanep; dan Noor, Mohd Ali Mohd. "Kesan Bantuan Zakat terhadap Kualiti Hidup Asnaf Fakir dan Miskin", The Journal of Muamalat and Islamic Finance Research 1(1), , (2004), 151-166.

Yusuf al-Qardawi (2006) Figh al-Zakah: Dirasah Muqaranah li Ahkamiha wa Falsafatiha fi Daw' al-Qur'an wa al-Sunnah, Jilid 2, Qahirah: Maktabah Wahbah 
Khairul Azhar Meerangani

154 - Fakultas Syariah dan Hukum UIN Syarif Hidayatullah Jakarta 